\title{
Waste management development to protect water resources in the Niger Delta Region
}

\author{
J. I. Ogolo \\ Department of Business Administration, Niger Delta University, \\ Wilberforce Island, Bayelsa State, Nigeria
}

\begin{abstract}
This paper is aimed at assessing the present system of waste management development to protect the water resources in terms of methods of disposal, recycling, suitability and waste management practices in the Niger Delta Region of Nigeria with a view of identifying the obstacles to its efficiency and proffer alternatives towards effective utilization of waste materials for employment and wealth generation as a means of sustainable development. A sample of five out of seven states of the region is used for the assessment. A survey method using questionnaire and personal interview of the key operators in waste management, in various states and local government area was employed. It is found that in all the states, the waste management practice was to collect, transport and dump the waste material, either in a borrow pit or in a river thereby contaminating the water resources in the Niger Delta Region in Nigeria. It is also found that in the main obstacles that militated against the management and development of waste materials were absence of legal framework; lack of political will and non availability of modern technological infrastructure and expertise. It is recommended that government or through its environmental agencies or indirectly through partnership with private sector in major towns in their state establish recycling, incinerating companies/plants with modern technological expertise to take care of waste materials. It is also recommended that state governments through its state executive councils and its legislative arms should enact laws to oversee the success of these plants in relation to conversion of waste to value added product. In conclusion, when these recommendations are considered and put in practice this will lead to a more viable economy, cleaner, healthier, and aesthetic surrounding thereby providing a sustainable waste
\end{abstract}


management development that protects the water resources within the Niger Delta Region in Nigeria.

Keywords: recycling, waste management, water resources, solid waste, domestic waste, commercial waste, industrial waste, waste minimization, refuse, constraints.

\section{Introduction}

The management of waste in order to protect the water resources constitutes one of the most serious environmental problems facing government at all levels (federal, state and local) in the Niger Delta Region of Nigeria. According to Iwuji [1], solid waste is described as any non-flowing substance that results from human activities which is relatively unwanted or not useful to man. Waste generation and disposal have been in practice before human civilization. In the early days before the advent of the industrial revolution, the major constituent of solid waste products was bio-degradable in nature, which made it very easy to be handled and disposed of. However, with increasing population, industrialization, rapid urbanization, municipal solid wastes are piling up much faster than can be satisfactorily disposed. The conventional approach-based on collection and disposal has failed to provide effective and efficient services for the urban centers in the country (Oladipo [2]).

Until recently, Nigerians were not too concerned with solid waste disposal; their concern had never gone beyond the physical removal of waste from the roadsides. It has been and is still a common practice in the country to dispose of refuse by this most expedient method. This is not different from what is seen in the five states in the Niger Delta Region, where indiscriminate dumping of refuse is on the increase. Virtually all the streets are littered with refuse, most of which comprise of waste vegetable, food, dead fish, unserviceable vehicles, worn out furniture and others. This practice unfortunately helps in spreading endemic diseases like malaria, typhoid, cholera, and diarrhea, including the six-killer diseases. Besides the change in quantity as a result of increasing population and consumption pattern, there is also a change in generation in municipal solid waste, which is non-biodegradable in nature, further complicating the problem of a satisfactory disposal of these wastes. The disposal of solid waste, especially the hazardous one on the land without careful planning and management presents danger to humans, animals, plants, water and the entire eco-system.

The problems of environmental deterioration and degradation emanating from man's activities to support and attain a good living standard prompted the call for an "Earth Summit" which took place in Rio de Janeiro Brazil in 1992. The conference was fundamentally organized to discuss the issue of achieving environmental sustainability. Aina [3] noted that:-

The attainment of sustainable development requires a clear understanding by all people, the causes and effects of environmental degradation and measures for redemption or protection of water resources in the Niger Delta. 


\subsection{Objectives of the study}

The main objectives of this study are:

1. To investigate the extent to which enabling and available laws on the environment especially on the issues of environmental sanitation have helped to curb the problems of indiscriminate refuse dumping with reference to water resources contamination in the Niger Delta Region.

2. To suggest a more sustainable, waste management method, for waste collection, minimization and evacuation to protect the water resources in the Niger Delta.

3. To find out the reasons behind indiscriminate dumping of refuse around the streets of the Cities in the Niger Delta Region and its health implications.

\subsection{Research hypothesis}

To provide a degree of validity to this research, the following hypothesis were formulated

1. There is no significant relationship between reuse, recycling, reduction and attainment of environmental sustainability in the Niger Delta Region.

2. There is no relationship between indiscriminate waste disposal and increased health hazards due to water pollution in the Niger Delta Region.

\section{Review of the related literature}

The overall goal of waste management is to collect, treat and dispose of materials generated by all urban population, groups in an environmentally and socially satisfactory manner, using the most economical means available. Dede [4] categorized solid waste based on their generation or production. They include domestic, commercial and industrial waste.

\subsection{Methods of solid waste disposal}

Although solid waste is an asset when properly managed, its volume in the Niger Delta Region has continued to increase tremendously in recent times as a result of socio-economic development including wage increase and industrial activities. In Niger Delta, much has been and is still being invested on municipal solid waste management (MSWM) in our cities. But little progress has been made because of several financial, technological and institutional constraints within the public and private sectors apart from the erratic growth of housing units in the inner core of urban cities. Furthermore, faulty or non-existence maintenance collection trucks/vehicles as well as lack of spare parts contributes to high percentage of idleness among the Authority of waste collection. Hence, uncollected waste accumulates on the streets clog drains when it rains, which often leads to flooding. Waste can also be carried away by runoff water to rivers, lakes and seas, affecting the ecosystem (Okpokwasili and Ogbugbue [5]). Today, waste disposal methods have been classified into the following categories: open 
dumps, municipal incineration, backyard burning, composting, ocean dumping, and sanitary landfill

\subsection{Suitable management of solid waste integrated approach}

In order to handle the ever-growing volume of wastes, the proper investments need to be made and implemented. The general approach to tackling the problems of waste management in the Niger Delta has always been to pump in money and equipment with little or no analysis as to their main causes (Oladipo [2]). In recent time, however, there is the general consensus that proper management of municipal solid waste, which is more compactable with an environmentally sustainable development, is called "integrated waste management". For example, some problems have to do with the attitude of the people, waste management staff, private formal and informal enterprises and waste pickers, institutional framework, the environment and general changing social, institutional, legal and even political conditions (Ibid). The integrated approach therefore, consists of a hierarchical and coordinated set of action that reduces pollution, seeks to maximize recovery of reusable and recycling materials and protect human health and the environment. It also aims to be socially desirable, economically viable and environmentally sound (Okpokwasili and Ogbugbue [5]). This approach should also be adapted to the local conditions when effectively implemented in the Niger Delta Region. Integrated waste management has the following structures namely Waste minimization, Reuse and Recycling

\subsubsection{Waste minimization}

Waste minimization is one of the most important aspects of integrated waste management. This is a preventive action that seeks to reduce the amount of waste that individuals, businesses and other organization generate. By not creating waste, fewer collection vehicle and a fewer number of refuse collectors would be needed; fewer and smaller waste handling facilities would be required and it would extend the life of the landfills. Minimization of waste can be achieved by enacting public policies that discourages the production and consumption of disposal products contain unnecessary packaging materials, it can be achieved also by encouraging the production, sale and consumption of reusable or recyclable products and enacting the public policies that encourage the production, sale and consumption of long-lasting products, large size products, reparable and light weight products. These measures can only be achieved, if government make laws in these directions (Medina [6]).

\subsubsection{Reuse}

This is the next step to be taken, immediately waste minimization has taken place or is implemented. The approach aims at promoting the reuse of products and materials. Reuse consists of recovery of items to be sued again, perhaps after some cleaning and refusing the materials are used again. The materials and products here save energy, water, reduce pollution and lessen society's consumption of natural resources compared to the use of non-reusable products. 
Reuse materials save money and serve as a source of revenue for the companies that implement them.

\subsubsection{Recycling}

Recycling, recovery of resources and protecting of water resources as the main focus of this study, is given the highest priority in the integrated management approach, is the process of using waste materials to or produce other products. After collection materials (e.g. textiles, leather, ceramics, wood, metals, plastics, paper and corrugated cardboard) are separated and processed into new materials or products. The approach is very helpful considering the increasing cost of raw materials in Nigeria particularly in the Niger Delta for manufacturing industries, it also prevents emission of many green house gases and water pollution, saves energy, supplies valuable raw materials to industries, creates job opportunity, stimulates the development of greener technologies, reduces the need for new landfills, incinerators and conserves resources for our children's future.

In Niger Delta Region, municipal authorities lack recycling program, therefore, individuals and private enterprises undertake recycling activities. This is unlike the developed world, where municipalities have created recycling programs, where individuals and businesses separate their recyclable material in a different container before they are mixed with the rest of their refuse (Medina [6]). Some developed countries use Materials Recovery Facilities (MRFs). MFRs are plants where recyclable materials are recovered, sorted, and processed for sale to industry. The MRFs make use of different types of magnetic and pneumatic equipments, conveyor or belt as well as human sorters to classify the recyclable materials. Recycling also occurs at the household level, particularly in low-income areas. This begins with the use of plastics, paper, bottles, cans, for domestic purposes. These materials are disposed off only when they are no longer of any use to their owners (Boadi and Kuitmen [7]). Izugbara and Umoh [8] found that Ngwa people of South-Eastern Nigeria use careful waste segregation and sorting, selective burning and burying, composting and conversion etc to manage the solid waste they generate. It is believed that if the people were supported by appropriate input from modern technology, their efforts would offer scope for meeting the challenges and addressing the limitation of current waste management in urban areas.

\subsection{Constraints on sustainable waste management in the Niger Delta of Nigeria}

As urbanization continues to take place, the management of waste becomes a major public health and environmental concern in urban area of many developing countries. The concern is serious, particularly in the capital cities, which are often gateways to the countries for foreign diplomats, businessmen, and tourists. Poor visual appearances of these cities have negative impacts on official, tourist visits and foreign investment. Recognizing its importance, a number of developing countries have requested collaboration of external support agencies, both bilateral and multilateral, in improving the problems of waste management for the past 20 years or so. Although some projects succeeded in 
providing lasting impacts on the management of waste in the recipient States and cities, many failed; continued activities after the external support agencies increased their support. This unsustainability of collaborative projects is due to various technical, financial, institutional, Economic and social constraints which vary from country to country and from city to city as developing countries and cities within them differ in solid waste management problems. The operators and external agencies have different and little resources available to resolve the problems. Therefore, in order to ensure the sustainability of collaborative projects, the various constraints of both developing and external support agencies should be carefully examined and an approach is developed to remove such constraints within the context of the collaborative projects.

A typical solid waste management system in the Niger Delta of Nigeria displays an array of problems including low collection coverage and irregular connection services; crude open dumping and burning without air and water pollution control; the breeding of flies, and the handling and control of informal waste picking or scavenging activities. These public health, environmental and management problems are caused by some of the factors mentioned above which have posed itself as a hindrance towards the development of effective waste management systems (Bartone [9]).

\subsubsection{Technical constraints}

In Niger Delta Region, there is typically lack of human resources at both the states and local government levels with technical expertise necessary for solid waste management planning and operation. Many officers in charge of solid waste management particularly at the local level have little or no technical background or training in engineering or management. Without adequately trained personnel, a project initiated by external consultants could not be continued. Therefore, the development of human resources in the country of external support is essential for the sustainability of the collaborative project. Research and development activities in waste management are also often a low priority in developing countries. The lack of research and development activities leads to the selection of inappropriate technology in terms of the local climatic and physical conditions, financial and human resources capabilities, and social or cultural acceptability. As a result, the technology selected can never be used, weighing the resources spent and making the project unsustainable.

\subsubsection{Financial constraints}

Generally waste management is given a very low priority in developing counties except perhaps in capital and large cities. As a result, very limited funds are provided to the waste management sector by the governments, and he levels of services required for protection of public health and the water resources are not attained. The problem is acute in the local government level where the local taxation system is inadequately developed and therefore, the financial basis for public services, including waste management, is weak. However, user's ability to pay for the services (inform of user's service charges) is very limited in poorer developing countries, and their willingness to pay for the services which are irregular and ineffective, is not high either. An effective strategy for raising 
funds needs to be searched in any collaborative project to ensure its sustainability. In addition to the above, many local government lack good financial management and planning for instance, in a town in a developing country, over $90 \%$ of the annual budget provided for waste management was up within the first six months. The lack of financial management and planning, particularly cost accounting, depletes the limited resources available for the sector even more quickly and causes the solid waste management services to halt for some periods, thus losing the trust for service users.

\subsubsection{Institutional constraints}

Several agencies at the national level are usually involved at least partially in solid waste management. However, there are often no clear roles/functions of the various national agencies defined in relation to waste management and also no single agency or committee designated to coordinate their projects and activities. The lack of coordination among the relevant agencies often results in different agencies becoming the national counterpart to different external support agencies for different solid waste management collaborative projects without being aware of what other national agencies are doing. This leads to duplication of efforts, wasting of resources and unsustainability of overall waste management programs. There is also low priority given to the sector, the institutional capacity to local government agencies involved in solid waste management is generally weak, particularly in small cities and towns. Local ordinance/by-laws on solid waste management institutions are not provided with clear mandates and sufficient it resources to fulfill the mandates. The lack of coordinating body among the local governments often leads to disintegrated and unsustainable programs for solid waste management.

\subsubsection{Economic constraints}

Economic and industrial developments play key roles in waste management. Obviously, enhanced economy enables more funds to be allocated for waste management, providing a more sustainable financial basis. However, by definition, developing countries have weak economic basis and hence insufficient funds for sustainable development of waste management systems. Local industry, which produces relatively inexpensive solid waste equipment and vehicles, will reduce or in some cases could eliminate totally. The need for importing expensive foreign equipment vehicles and therefore foreign exchange will arise. However, lack of industry manufacturing waste equipment and spare parts and a limited foreign exchange for importing such equipment/spare parts are the rule rather than exception in developing countries. Also in small developing counties, waste recycling activities are affected by the availability and process recycling materials. For instance, the recycling of waste paper is possible only when there is a paper mill within a distance for which the transportation of waste paper is economical. The weak industry for recycling activities is a common constraint for the improvement of solid waste management in developing countries. 


\subsubsection{Social constraints}

The social status of waste management workers is generally low in both developed and developing countries, but more so in developing countries than developed countries. This owes much to a negative perception of people regarding the work, which involves the handling of waste or unwanted materials. Such people's perception leads to disrespect for the work and in turn produces low working ethics to their work. The lack of public awareness and school education about the importance of proper waste management for health and well being of people severely restricts the use of community-based approaches in the Niger Delta Region in Nigeria

\section{Methodology}

The study area includes the Capital Cities of the five sample states that made up the Niger Delta Region in Nigeria. These cities are Yenegoa in Bayelsa State, Asaba in Delta State, Port Harcourt in Rivers State, Uyo in Akwa Ibom State and Calabar in Cross River State. Survey method was adopted so as to have a critical examination of current conditions or practices to waste management development in order to proffer more suitable solutions from respondents, cluster/quota sampling technique was used to get the sample population drawn from the capital cities in the five sample states in the Niger Delta. The sample of 500 respondents drawn from the five states Ministry of Environment, the operators and management of waste materials in their various states. The sampling technique used for the sample size was convenience and quota sampling techniques. The primary and secondary sources of data collection were used for the study. They comprise of the following (i) Questionnaire (ii) Interview (iii) Data from Journals and (iv) Observation.

\subsection{Questionnaire distribution and analysis}

The questionnaire method was adopted to reach the various elements of the population understudy at least to get the feelings, reactions and opinions of the cross section of the people as regards waste generation and management to protect the water resources in the Niger Delta Region. The questionnaire was administered face to face with open ended questions to give the respondents freedom to answer at their base. In analyzing and testing the hypothesis, the use of tables, percentages and Chi-square were employed for calculating the relationship existing between the variables (dependent and independent).

Out of the 500 copies of questionnaire distributed to the selected respondents in the five states understudy, only $450(90 \%)$ copies were properly completed and returned. The other 50 copies of questionnaire $(10 \%)$ were misplaced, lost and some unfilled. Thus, such copies of questionnaire were not utilized for this study.

The Chi-square (X2) is represented as follows: where X2 $=$ Chi-square $=$ the summation of the observed frequency minus the expected frequency $0=$ the observed frequency. In conjunction with the above analysis, we can say that at 
95\% confidence level, the careless and indiscriminate disposal of refuse on the streets of the Niger Delta Region has been affecting people's health due to the seepage of the waste thereby contaminating the water resources. Even though some other factors could result to health hazards, indiscriminate refuse disposal and inadequate management have been viewed as major factors militating against people's health.

\section{Results}

In analyzing hypothesis one; "there is no significance relationship between waste reuse, reduction, recycling and the attainment of sustainable environment in the Niger Delta" in line with question number 2 which states, "Do you think that, environmental sustainability can be achieved by the application of appropriate measure in waste reduction, reuse and recycling in the Niger Delta?" applying the decision rule, which states that, if the calculated chi square is greater than the table X2, we will reject the null hypothesis, but if the table X2 is greater than the calculated chi square, we will accept the hypothesis. We are therefore rejecting the null hypothesis, which states that there is no significant relationship between waste reuse, reduction, recycle and the attainment of sustainable environment in the Niger Delta, since the calculated hypothesis 16.5 is greater than the table chi square 3.841 .

In analyzing hypothesis two which states there is no relationship between indiscriminate waste disposal and increased health hazards due to water pollution in the Niger Delta region, using Chi-square the calculated X2 values was 53 while the table chi-square was 3.841, which means that the alternate or research hypothesis was accepted while the null hypothesis was rejected. It is obvious and glaring here; that most respondents admitted that, if nothing is done to control the rate of indiscriminate refuse dumping on the streets in the capital cities of Niger Delta and market places that the individual residents will continue to live at the expense of their lives. Gathering, from the respondents, during the distribution of the questionnaires, it was deduced that most areas lacked waste recycle bins around them, therefore, considering the sophisticated and expensive life that surrounds the cities and having been among the low income earners, they found it difficult to transport themselves to the appropriate and legally approved designated disposal sites in the town. It was palpably clear to agree that majority of the people living in the cities are dying in silence because as poor people, they have no means of expressing their feelings towards what is happening in the environment which they are part and parcel of. This is why Keller [10] raised an alarm on the grave implications of giant heaps of refuse literally standing out all over the places especially those close to residential homes and market places as though to glorify the cities as a haven for garbage. Okpokwasili and Ogbugbue [5] also confirmed of the refuse dumps are located very close to residential areas, markets, farms, roadsides and creeks which in turn pollute the water and they contribute to increase in health hazards in the cities. No wonder, there is now a joke among environmentalists in the Niger Delta, that if you want to craft an environment ideal for breeding new diseases 
and spread them rapidly, then come to most cities in the Niger Delta Region especially the markets.

\section{Recommendation}

Every academic research aims at identifying an already existing problem and proffering solution to it and having identified the problems of municipal waste management development, the following recommendations are proposed:

1. The government should discourage those waste management practices that destroys environment especially open dump method which has been a major source of land degradation and degeneration, air pollution, surface and underground water pollution. A critical look at our disposal sites shows that we are continually wasting our precious land instead of reclaiming our depressed land for future use, we are rather rendering it useless and hazardous with refuse dumps

2. Niger Delta State Government should also have it in mind that for any state to succeed in all spheres of social, economic and political growth especially in the management of waste, professionals that majored in environmental studies and management should be appointed to manage refuse dumps using the most appropriate methods. Reasonable funds should also be pumped into this department without thinking of self-gratification and aggrandizement

3. The government on the issue of waste sorting and segregation before disposal should encourage public lectures and awareness campaign. This will make all hands to be on deck, everybody contributing their quota towards making the Cities of Niger Delta liveable

4. Solid waste recycling, though it is presently practiced by some industries, should be encouraged using the appropriate technology. This will discourage scavenger's activities and protect them from its attendant's health hazards. When the environment is safe, man is safe and so, there should be attitude change towards refuse disposal. The government should ensure that refuse is not only collected and disposed but must have to undergo various processes not waste minimization in which recycling is its major part so as to reduce these refuse to its barest minimal.

5. The citizens should adopt the step-by-step processes of recycling solid waste emulated above in this write-up and this can be achieved through public education and sensitization.

6. Solid waste management regulation and edicts on waste disposal and sanitation should be enforced not minding whose toes are trampled upon.

7. The enlightened citizens should act as watchdogs to ensure that government and corporations meet environmental pollution control targets.

\section{Conclusion}

In this study, it has been possible to identify and attribute the problem of refuse disposal to poor waste management system by the government coupled with 
nonchalant attitude shown by the public. It is believed that if the leaders can give the populace good direction, waste management problem can be solved as an environmental and economical issue through reusing and recycling.

This study also realizes that refuse management through recycling is more efficient than any other refuse management processes. The cost of managing refuse through recycling is safer, cheaper and economically viable than any other system of refuse disposal like incineration or landfill, putting into consideration cost of land, building incinerator to mention but a few.

\section{References}

[1] Iwuji, C. Solution to Urban Refuse Disposal Problem, the Statesman pp. 11 Monday October 12, 1992.

[2] Oladipo, M. Foundation of Social Science Research, A Methodological Guide for Students: University of Port Harcourt press p.56-60, (1996)

[3] Aina, O. A. (1996) "NGOs Fight for Environmental Protection", Daily Sunray, Tuesday Feb. 9 1996, p.4.

[4] Dede, E. B. FNES Realizing Effective Medical Waste Management from Cradle to Grave in Nigeria in Solid Waste Management in Ilie twenty-first century, Nigeria, Port Harcourt - Nigeria, p.30-35, July - 5- 7 (2006).

[5] Okpokwasili, G. C. and Ogbugbue, C. J. Solid waste disposal system in Nigeria, "their merits, demerits and sustainable investment opportunities". In solid waste management in the twenty first century, Port Harcourt, Nigeria, July 5-7, (2006)

[6] Medina, M. Globalization development and Municipal waste management in third world cities. El Colegio de la Frantea Norte, Tijuana Mexico. pp.1-38 (2002)

[7] Boadi, K. O. and Kuitmen, M "Municipal solid-waste Accra Metropolitan Area, Ghana". The Environmentalist 23:211-218, (2003).

[8] Izugbara, C. O. and Umoh, J. O. "Indigenous waste management practices among the Ngwa and south eastern Nigeria. "Some lessons and policy implications". The environmentalist 24 (2): 87-92 (2004)

[9] Bartone, C. R. "The role of private sector in developing countries: key to success. Paper presented at ISWA Conference on waste management - Role of the private sector, Singapore, 24-25 Sept. 1995. 